\title{
Mandatory CSR in India: Proponents For and Against
}

\author{
Geetika Jaggi \\ Assistant Professor, PGDAV College(M), Delhi University
}

\begin{abstract}
The concept of CSR is underpinned by the idea that corporations can no longer act as isolated economic entities operating in detachment from broader society. CSR is understood to be the way firms integrate social, environmental and economic concerns into their values, culture, decision making, strategy and operations in a transparent and accountable manner, and thereby establish better practices within the firm, create wealth and improve society.

India is the only country in the world with legislated corporate social responsibility, the amendment has come in forth the Companies Act, 2013 wherein it mandatory for every registered company to spend on CSR activities, The paper intends to study the concept of mandatory CSR and the proponents for and against the legislation and recommendation for effective implementation.
\end{abstract}

Keywords:- CSR, Companies Act 2013, Mandatory CSR, Section 135, Schedule VII

\section{Concept CSR}

"Social responsibility (is the) responsibility of an organisation for the impacts of its decisions and activities on society and the environment through transparent and ethical behaviour that is consistent with sustainable development and the welfare of society; takes into account the expectations of stakeholders; is in compliance with applicable law and consistent with international norms of behaviour; and is integrated throughout the organisation."

Working definition, ISO 26000 Working Group on Social Responsibility, Sydney, February 2007

Corporate social responsibility (CSR) is also known by a number of other names. These include corporate responsibility, corporate accountability, corporate ethics, corporate citizenship or stewardship, responsible entrepreneurship, and "triple bottom line," to name just a few. As CSR issues become increasingly integrated into modern business practices, there is a trend towards referring to it as "Responsible Competitiveness" or" Corporate Sustainability

The concept of is underpinned by the idea that corporations can no longer act as isolated economic entities operating in detachment from broader society. CSR is understood to be the way firms integrate social, environmental and economic concerns into their values, culture, decision making, strategy and operations in a transparent and accountable manner, and thereby establish better practices within the firm, create wealth and improve society

\section{Research Methodology}

The research is based on the information collected from various secondary sources including journals, articles and various research based websites

\section{Concept of Mandatory CSR in India}

According to Section 135 of the Companies Act 2013 every registered company with

\begin{tabular}{|l|l|l|l|}
\hline $\begin{array}{l}\text { Turnover of Rs } 1000 \text { crore and } \\
\text { more OR }\end{array}$ & $\begin{array}{l}\text { Net worth of Rs } 500 \text { crore and } \\
\text { more }\end{array}$ & $\begin{array}{l}\text { Net profit } \\
\text { OR }\end{array}$
\end{tabular}

will have to spend at least $2 \%$ of their three year average annual net profit on CSR activities in each financial year. The provision of Section 135 came into effect on April 1, 2014.

(Foreign companies are also covered under CSR provisions based on the profits of their Indian Business Operation)

Schedule VII of the act deals with the activities that can be undertaken by a company to fulfil its CSR obligations include:

- $\quad$ Eradicating hunger and poverty

- $\quad$ Promotion of Education; employment enhancing vocational skills

- $\quad$ Promoting Gender Equality and Empowering Women

- $\quad$ Ensuring Environmental Sustainability

\footnotetext{
${ }^{1}$ Net Profit means profits as per the financial statements excluding profits generated outside India through overseas branches or subsidiaries and any dividend received from other companies in India
} 
- $\quad$ Contribution to Prime Minister's National Relief Fund or any other fund set up by the Central or State Government for socio economic development and relief and funds for welfare of SC, ST, OBC, Minorities and Women

- $\quad$ Such other matters that may be prescribed:

$\checkmark \quad$ Protection of national heritage, art and culture including restoration

of buildings and sites of historical importance and works of art;

setting up of public libraries; promotion and development of

traditional arts and handicrafts

$\checkmark \quad$ Measures for the benefit of armed forces veterans, war

widows and their dependents

$\checkmark \quad$ Training to promote rural sports, nationally recognised

sports, and Paralympics sports and Olympic sports.

$\checkmark \quad$ Contributions or funds provided to technology incubators

located within academic institutions which are approved by

the Central Government.

$\checkmark \quad$ Rural development projects

Activities not included: donating funds to political parties or spends to benefit own employees and their families will not be counted as a company's CSR

Additional Requirements:

CSR Committee: consisting of at least three directors, including an independent director should be formulated.

(However, exempts unlisted public companies and private companies that are not required to appoint an independent director from having an independent director as a part of their CSR Committee and stipulates that the Committee for a private company and a foreign company need have a minimum of only 2 members)

The committee shall formulate and recommend to the board CSR Policy expenditure to be incurred on CSR activities

- CSR Policy: should reflect list of projects company want to undertake, time line of the project, a statement that corpus would include the mandatory profit requirement, any income arising therefrom, and surplus therefrom

- Disclosure: Any activity done part of the CSR policy must be made available on the company's website and disclosure thereof should be made in the in Board of Director Report

- Company may set up a trust, or section $8^{2}$ company or society or foundation to facilitate implementation of CSR activities: Thus Group CSR projects or joint CSR projects are permitted

- $\quad$ CSR activities should be within India

- $\quad$ Surplus generated from CSR activities should not be treated as business profit of the company and need to be ploughed back in CSR activities.

\section{Proponents for Mandatory CSR}

India is the only country in the world with legislated corporate social responsibility. According to industry estimates around 8000 companies will fall into the ambit of CSR provision and would translate into estimated CSR spend of Rs 10000 crore to Rs 15000 crore. With higher economic growth and increase in companies profits, this mandatory spending will go up.

The current provision are not a case of Government subsiding its responsibility to the corporate sector as per the industry estimate the estimated amount of CSR spending in context of total social sector is $1 \%$ (rough estimate) albeit the corporate sector would be helping hand to the Government in contributing to the inclusive growth of the country.

The provision stated under section 135 according to some corporate would act as $2 \%$ implicit tax with a key difference that, under explicit taxation there is no guarantee that money collected by the Government where it would be spent, implicit tax gives control to the companies over disbursement of their own funds with greater incentives to choose the right projects that have synergies with their line of operations. Thus the likely result would be better project delivery.

The provision does not distort economic objective as the CSR expenditure is an appropriation of ex post profit and not allocation of cost that would hinder economic objective.

\section{Proponents against Mandatory CSR}

Mandatory CSR may impose disproportionate cost on smaller and younger companies for whom net profit(internal source of capital) forms important source of investment. Forcing such companies to make

${ }^{2}$ Section 25 of Companies Act 1956 replaced with Section 8 in Companies Act 2013 
mandatory CSR expenditure would increase the opportunity cost of funds therefore many believe that CSR spending should be voluntary ,the company would undertake if the perceived benefits outweigh opportunity cost.

Under the current provision there may be an issue of coordination of CSR projects across companies in a particular region to prevent duplication of and overinvestment in similar types of CSR projects which may also lead to regional inequality(as many projects may be cantered at particular geographical location).

Under the current Income Tax, the CSR spending is not treated as expenditure, industrialist propose that it should be tax deductible as this spend is an integral cost of business

Mandatory CSR activities may not create an impact as businesses may just look at allocating money for such activities rather than seeking optimal ways for addressing social issues, According to Michael E Porter , Professor Harvard Business School Organizations just sprinkle money around, but there will be no social impact and no solution arises from this approach.

\section{VI.Recommendation}

Coordinating agency at the centre or may be at the state level must be constituted so that CSR spending of companies harmonised and lead to successful implementation of CSR initiatives which may eventually lead to balanced regional development.

Also pooling of resources and building synergies to implement best CSR practices to scale up projects and innovate new ones to reach out to more beneficiaries that will increase the impact of their initiative.

Activities mentioned under Schedule VII as recommended CSR activities are restricted, the scope may be widened up by including other critical areas such as Human Rights, Disability etc. Also contribution to the Prime Minister's National Relief Fund and other such funds as established by the central or state government are included in the schedule, however Prime Minister's National Fund itself is not a government body and is not even answerable to either houses of the parliament (Verdict by CIC, A.K Goel vs PMO, 2009) therefore the PM Relief Fund should be excluded from the list of funds.

Activities providing "Exclusive" benefit to employees and families are not considered as CSR some (even if occasional/ smaller) benefit to the local community, can also result in the activity being listed as CSR activity.

Industrialist propose amendment in the Income Tax Act, 1961 and CSR expenditure be tax deductible, as this spend is an integral cost of business.

The success of CSR lies in practicing it as a core part of a company's development strategy. It is important for the corporate sector to identify, promote and implement successful policies and practices that achieve triple bottom-line results ; profits, protection of environment and fight for social justice

\section{References}

[1]. http://articles.economictimes.indiatimes.com/2014-01-29/news/46782747_1_csr-policy-csr-committeenew-companies-act

[2]. http://www.livemint.com/Politics/Nf56hLBZSiXJ2tw71S0UNN/Mandatory-CSR-may-not-createimpact-Michael-E-Porter.html

[3]. http://www.business-standard.com/article/companies/an-overview-of-csr-rules-under-companies-act2013-114031000385_1.html

[4]. http://www.iisd.org/business/issues/sr.aspx

[5]. http://www.iisd.org/pdf/2007/csr_guide.pdf

[6]. http://www.caclubindia.com/articles/corporate-social-responsibility-under-the-companies-act-201319132.asp

[7]. http://www.nfi.org.in/sites/default/files/nfi_files/Comments\%20on\%20draft\%20CSR\%20rules.pdf

[8]. http://www.kpmg.com/IN/en/IssuesAndInsights/firstnotes/Documents/First_Notes_28Feb14_CSR_Rules.pdf

[9]. http://www.cii.in/ 